\title{
A CRITICAL APPROACH TO FUNCTIONING TRIPLE LITERARY THEORIES IN THE LITERATURE OF CHILDREN AND ADOLESCENTS
}

\section{UMA ABORDAGEM CRÍTICA PARA O FUNCIONAMENTO DE TEORIAS TRIPLAS LITERÁRIAS NA LITERATURA DE CRIANÇAS E ADOLESCENTES}

\section{UN ENFOQUE CRÍTICO PARA EL FUNCIONAMIENTO DE LAS TEORÍAS LITERARIAS TRIPLES EN LA LITERATURA INFANTIL Y JUVENIL}

\section{Alireza Saghir ${ }^{1}$ Mahmoud Firouzimoghaddam ${ }^{2 *}$ Maryam Jalali ${ }^{3}$ Mehyar Alavimoghaddam ${ }^{4}$}

\begin{abstract}
There are several theories about the critique of children's and adolescent literature. In this study, two theories that are more popular are reviewed and discussed: "Book-based or textbased criticism and child or audience-based criticism" of course, one can add to these two theories, the third, author-based. Undoubtedly, by examining and understanding the impact of the three theories of "audience-based, author-based, and context-based" on children's and adolescent works, more desirable results can be obtained in proving the worth or weakness of the works. Researcher seeks to critically examine children's and adolescent works based on three theories and believes that the function of triple theories in children's and adolescent works differs from that of adults and this difference is due to the specificity of the perception and understanding of the audience that must be taken into account. The method of descriptive-analytical research and data collection is often library-based.
\end{abstract}

Keywords: Literary Theories, Critical Look, Text-Based, Audience-Based, Author-Based.

Resumo: Existem várias teorias sobre a crítica da literatura infantil e adolescente. Neste estudo, duas teorias mais populares são revisadas e discutidas: "Críticas baseadas em livros ou em texto e críticas baseadas em crianças ou em público", é claro, pode-se acrescentar a essas duas teorias, a terceira, baseada em autores. Sem dúvida, examinando e compreendendo o impacto das três

\footnotetext{
${ }^{1}$ Islamic Azad University, Torbat- e heydariye, Iran

2 Islamic Azad University, Torbat- e heydariye, Iran

${ }^{3}$ Islamic Azad University, Torbat- e heydariye, Iran

${ }^{4}$ Islamic Azad university, Torbat- e heydariye, Iran
} 
teorias "baseadas no público, baseadas no autor e baseadas no contexto" nas obras de crianças e adolescentes, resultados mais desejáveis podem ser obtidos para provar o valor ou a fraqueza das obras. O pesquisador procura examinar criticamente os trabalhos de crianças e adolescentes com base em três teorias e acredita que a função das teorias triplas nos trabalhos de crianças e adolescentes difere da dos adultos e essa diferença se deve à especificidade da percepção e compreensão do público que deve ser levado em consideração. O método de pesquisa descritivaanalítica e coleta de dados geralmente é baseado em bibliotecas.

Palavras-chave: Teorias literárias, Aparência crítica, Texto, Texto, Audiência, Autor

Resumen: Existen varias teorías sobre la crítica de la literatura infantil y juvenil. En este estudio, se revisan y discuten dos teorías que son más populares: "Crítica basada en libros o basada en texto y crítica basada en niños o audiencia" por supuesto, se puede agregar a estas dos teorías, la tercera, basada en autor. Sin duda, al examinar y comprender el impacto de las tres teorías "basada en la audiencia, basada en el autor y basada en el contexto" en las obras de niños y adolescentes, se pueden obtener resultados más deseables al demostrar el valor o la debilidad de las obras. El investigador busca examinar críticamente las obras de niños y adolescentes a partir de tres teorías y considera que la función de las triples teorías en las obras de niños y adolescentes difiere de la de los adultos y esta diferencia se debe a la especificidad de la percepción y comprensión de la audiencia que debe ser tenido en cuenta. El método de investigación descriptiva-analítica y recopilación de datos se basa a menudo en bibliotecas.

Palabras clave: teorías literarias, mirada crítica, basada en texto, basada en audiencia, basada en autor.

\section{INTRODUCTION}

Children's and adolescent literature refers to a group of literary works that; their very existence depends entirely on their hypothetical relationship with the particular audience, the child and the teenager; In other words, the literature in this group consists of a collection of writings, poems, and speeches that are created within the context and design of the way in which they interact and this relationship leads to arousal of feelings and aesthetic pleasure; It has special psychological and psychological effects on them and enhances their cognition. Investigating and understanding the impact of the three text-based, audience-based and author-based theories on children's and adolescent specialties can yield better results in proving the degree to which they are influenced or not.

\section{RESEARCH PROBLEM}

Nowadays, the scope of children's and adolescent literature research has expanded due to its importance and attention to the field, and many scholars have devoted their time to this field 
and some have directly or indirectly emphasized the three theories of "text-based, audience-based, and author-based". Parvin Salajegha discusses children's works in the book "From this Oriental Garden". Mohammad Hadi Mohammadi and Zohreh Qaeini have discussed the subject in the book History of Iranian Children's Literature. Ali Raouf writes a book entitled "A Guide for Criticizing Children and Young Adults" He has presented discussions in this area. Banafsheh Hejazi in part of the book "Literature for Kids and Teens Characteristics and Aspects" She has focused on the characteristics of children's and adolescent books. Seyyed Ali Kashefi Khansari in the book "Analytical Report of Criticism of Children and Adolescents Literature from 1979 to 1998" reviews the criteria of children's and adolescent books.

\section{RESULTS AND DISCUSSION}

Children's literature is not fundamentally different from the definitions commonly cited for literature. That is, not only is children's literature lacking in quality from adult literature; rather, it should be higher and more productive because it is for a young and inexperienced human being "The aim of children's literature is simply to entertain, enjoy and soothe the child" (HUNT, 1992: 90). Various opinions have been raised as to why children's literature; some have regarded children's literature as art and some as educational tools, others have considered it a way of conveying historical and cultural concepts and some have looked at it from a literary aesthetic point of view, some have also introduced children's literature as a means of transmitting the history and culture of different nations. So it should be kept in mind that "Children's literature is regarded as literature and must be adapted to the abilities of readers (child audiences)" (O'SULLIVAN, 2005: 13).

Traditionally, there have been two categories of theories about the critique of children's and adolescent literature: book based, child based (POLADI, 2005: 121) Of course; one can add to these two the third theory, the criticism of the author. Researchers can undoubtedly achieve better results by examining and understanding the impact of triple theories on children's and adolescent work. And one should not overlook its use in analyzing children's literature besides examining literary criticism in the great works of adults; because the world of children's literature, like adult literature, has features and delicacies that can be addressed to critics and literary theories, its value and beauty and on the other hand, the authors of the children's work showed the path of writing a useful work. The researcher considering the triple theories "text-based, audience-based and author-based" It can take a critical look at the works of children and adolescents and analyze some of the existing works 
with a view to the specific features that should be appropriate to the audience's understanding and understanding of these theories.

\subsection{A Critical Look at Text-Based Theory in Child and Adolescent Literature}

Literature is a kind of art, and the literary artist uses emotions and vocabulary, combines it and creates a literary and artistic work. In fact, tries to express thoughts and emotions in the most appropriate and beautiful terms so that the audience can enjoy reading and listening. In writing literary texts for children and adolescents, it is necessary to pay attention to the three basic elements of clarity, style, and beauty (JALALI, 2016: 85). The aesthetics of the text and the use of appropriate vocabulary are essential requirements of the author's attention in children's and adolescent literature and if the structure of the text undergoes changes and is not in line with the characteristics of the audience's interest, the audience will be averse. One of the types of literary criticism approaches is 'text-based'; No matter what the audience or author of the work, the critic merely examines and evaluates the text, regardless of the involvement of external factors. He evaluates the aesthetics and value of the text and examines the aesthetic elements that make it stand out. In fact, the author is more concerned with the form and appearance of the work than the content. The Russian formalism movement was one of the first movements in its literary studies to focus primarily on poetry itself. In this way they chose the form-oriented method and called it a formalist. It should be noted that focusing on the formal aspects of the literary text does not mean that they did not consider moral or social goals for literature (BRENTZ, 2008: 4). Rather, how important they were to express their moral, social, and political goals. The form and structure of literature in child literature is particularly important. Of course, the author's mere attention to the form and structure of the text may deter him from other features that are important to him. The researcher has taken a critical look at the issue from two perspectives:

\subsection{Absurdity and meaningless of the work}

One of the literary types of children is Nonsense verse. Nonsense verse is a kind of child poetry that has almost no meaning at all and weight, rhythm, tone are the main characteristics of Nonsense verse. Reading nonsense verse promotes the development of the minds of children under

the age of three and prepares them to understand the concepts between the ages of three and seven. Poetic imagination and the music of the nonsense verse make the child see the world in their 
imagination the way he or she wants and sometimes the animism of things and the characterization of animals, imagination engage the child in unrealistic but sweet-hearted imaginations (FOROUZAN, 2014: 76). children under the age of three enjoy listening to rhythmic and rhythmic lyrics; weight and rhyme are two key features of Nonsense verse; So the Nonsense verse are the best kind of poetry for the younger means the group of children. The musicality of this kind of poetry nurtures the toddler's mind and it prepares him to understand the meanings at an older age. There are no rules for singing Nonsense verse; Weight, rhyme and musical texture are pleasing to the main components of the form for the nonsense verse poems.

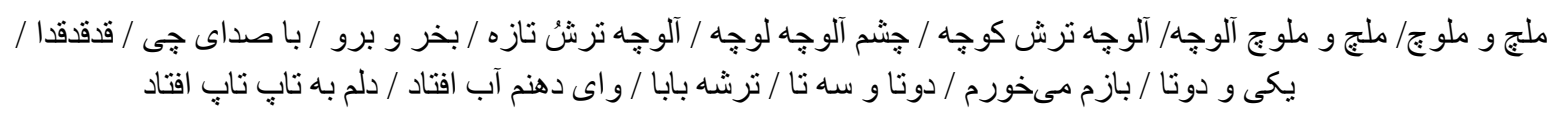
(NONSENSE VERSE, RAHMANDOUST, 2010: 30).

The use of linguistic elements is of particular interest. Music, repetition of words and consonants and vowels are effective in persuading the audience and making them attractive. It should be noted that the purpose of reading a poem to children is not necessarily to help the child understand the concept. Because inherently children are not looking for meaning in the poems; rather, they seek pleasure. In such works, the emphasis is solely on the form of beauty and language games.

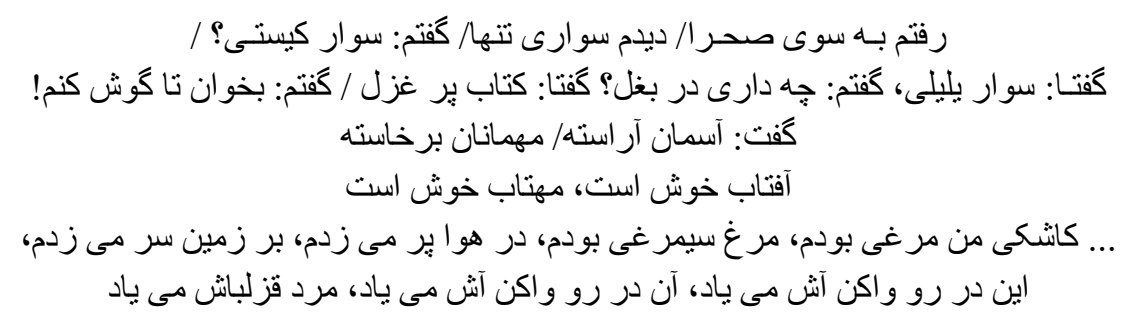

(HEDAYAT, 1986: 302).

The formation of Nonsense verse is based on their own language construction. That is to say, the poet pays attention to the meaning due to the use of specific language and lexical games and to the formation of the structure of language and rhyming. Unlike other poems or literary texts where language is meant to convey beauty in addition to creating beauty, in Nonsense verse, language is inherently important in itself. In addition to the linguistic highlights that draw critical attention to the text, the aesthetic elements and structural features of the work can be effective in highlighting the text, that is, the critic reviews and evaluates the work without regard to the elements and external factors of the text. 


\subsection{Verbal complexity}

Sometimes the author skips the words in the sentence to highlight the text, and the audience is forced to move the vocabulary to solve it. It is difficult for a particular audience to move the elements of a sentence and, as a result, it will be frustrating and unbearable for them, and eventually literature may become a negative element in their minds forever. In the younger age group children, if this verbal complexity occurs, it will be impossible for them to understand.

$$
\begin{aligned}
& \text { زيرا از اين بس/ بايد بكوشم } \\
& \text { تارخت باكى/ بر تن بيوشم باني }
\end{aligned}
$$

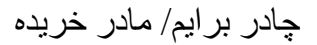

$$
\begin{aligned}
& \text { يك مهر و تسبيح/ خو اهر خريده }
\end{aligned}
$$

(Spring Worship, Mustafa Rahmandoust, Spring Season).

It seems as if the Chador is the entity of the sentence, but in this sense the meaning of the work is transformed; Therefore, the audience must replace the words "Chador" with "mother" in order to understand its logical meaning: "Mother bought me a Chador / and sister bought a rosary " This has not only damaged the creation of beauty in the word, but also its beauty.

\subsection{A Critical Look at 'Audience-Based' Theory in Child and Adolescent Literature}

Audience recognition has always been one of the fundamental criteria for criticizing children's and adolescent literature. The antecedent of this attitude can be found in the chants and a number of educational texts that have been opened up to children when speaking to children and have spoken well of their present. The notion that child poetry is simple, however, prompts some adult poets to write poetry in this area. Child poetry is difficult because of vocabulary constraints, limitations of images, limitations of concepts and themes, and even weight limits. For this reason, the poet's success in adult poetry is never the reason that he can succeed in child poetry (SANGARI, 2011: 32). Some researchers in the field of children's and adolescent literature find audience recognition to be critical in critique and believe that critics need to be aware of the child's world before criticizing the work. These scholars focus more on audience recognition than on text or author. The purpose of audience recognition in children's and adolescent literature is to "predict the audience's reactions to the text" (SAYYED ABADI, 2006: 21). Understanding the audience and their mental characteristics and cognitive understanding of what they read or the book they are writing is important. 
"Children's literature is written for the (audience) of the child. This literature faces limitations in some types of linguistic complexity. In other words, children's literature is like adult literature but simpler. To say that "children are small adults" is not an explanation for this kind of literature. They gain experience from adults" (NODELMAN, 2008: 155).

In this case, works written for children, like many adult works, must be realistically criticized and judged with competence. Some believe that children's literature is a literature that can convey messages, concepts, emotions, and thoughts, and subtly emotionally illuminate children's education and imagination. Children with mild feelings need some form of beauty that will help them grow mentally and emotionally. Beauty in children's literature is also a special form of beauty and art; In fact, children's literature is the use of appropriate and artistic words for children in the creation of writings and poems that can be used to convey children's understanding, understanding, emotions and needs, as well as conveying beauty and art (JALALI, 2017: 23).

The children's and adolescent author's attention to the correct use of language and content is a subject that is critical to the audience-based theory. This means that because the author has a specific audience; So it should be tailored to the linguistic and received features. The researcher has been critical of audience-based theory in three ways:

\subsection{Improper use of language in children's and adolescent works}

The child and adolescent author should use a language that is consistent with the audience's talents, talents, and abilities, and in the context of understanding the child and adolescent. The language of children and adolescents has special characteristics; therefore, any weakness that would lead to adult language would have an adverse effect on the audience. Inappropriate vocabulary in children's and adolescent works is commonly used by adults whose inappropriate use can damage the works.

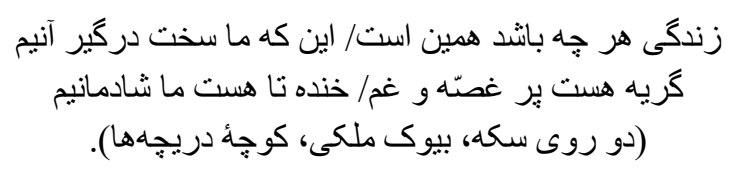

The use of the word 'engaged' rather than being confused to a specific audience is unclear, and this unfamiliarity of language contributes to inappropriate influence.

$$
\text { امّا جِون جرخاندم/ اين سو آن سو سرم را }
$$


(Pigeon, Light Source, Mustafa Rahmandoust).

$$
\begin{aligned}
& \text { يكباره ديدم كبوترم را/ ير ير زد باز آمد } \\
& \text { بنشست و دانه را ديد/ آبى خورد } \\
& \text { جرخى زد/ دلثاد دانه برجيد. }
\end{aligned}
$$

Applying certain traits of adult literature to audiences who do not understand them clearly will lead to ambiguity. Use of \{happy heart\} adjective instead of happy, it won't be nice for a group of minors who have not yet fully understood it.

\subsection{Improper use of content in children's and adolescent Works}

Sometimes authors of children's and adolescent works have created works that are difficult or impossible for the audience to understand, regardless of the audience and their perceptual characteristics. Since the theory of audience recognition is very important in children's and adolescent literature; it is necessary to get into the field of writing and critique of their works to know the characteristics of the audience. It should be noted that children have limited experience and information, and the use of complex themes will have no effect but neglect of the audience.

$$
\begin{aligned}
& \text { مىوزد بادى غريب/ دركويرى دور دست/ لاثندة يك كور خر / روى خاك افتناده است }
\end{aligned}
$$

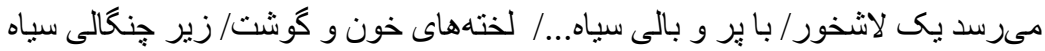

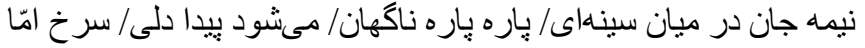

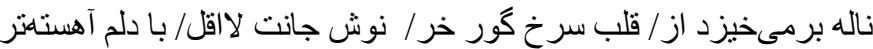

(KESHAVARZ, 1998).

In all the verses word or words such as: whimsical wind, distant desert, overcast, black feathers, blood clots, etc. are used that convey the fragrance of frustration and frustration to the audience. Such use of vocabulary and language proficiency not only does not weaken the child's dynamics and intellectual development but also weakens the seeker's morale. In the final verses, although the poet used humorous language; But the atmosphere of despair is so prominent that the true meaning is unclear. The latter part of the work will not be understood due to the limited experience and knowledge of the child and even the adolescent; In addition, the poet borrows its content from another poet who has actually created this content and theme for the adult audience. The child's mind is limited in vocabulary to the adult proportion and the subject of love and mysticism, which is largely the subject of adult poetry, has no meaning for the child.

In the following example, the poet has used elements that the audience will not be able to grasp. These difficult and meaningless uses of meaning are not compatible with the interest of the audience.

$$
\text { لحظةهاى خوب / مثل لحظةُ شروع دوستى / مثل لحظة طلوع }
$$




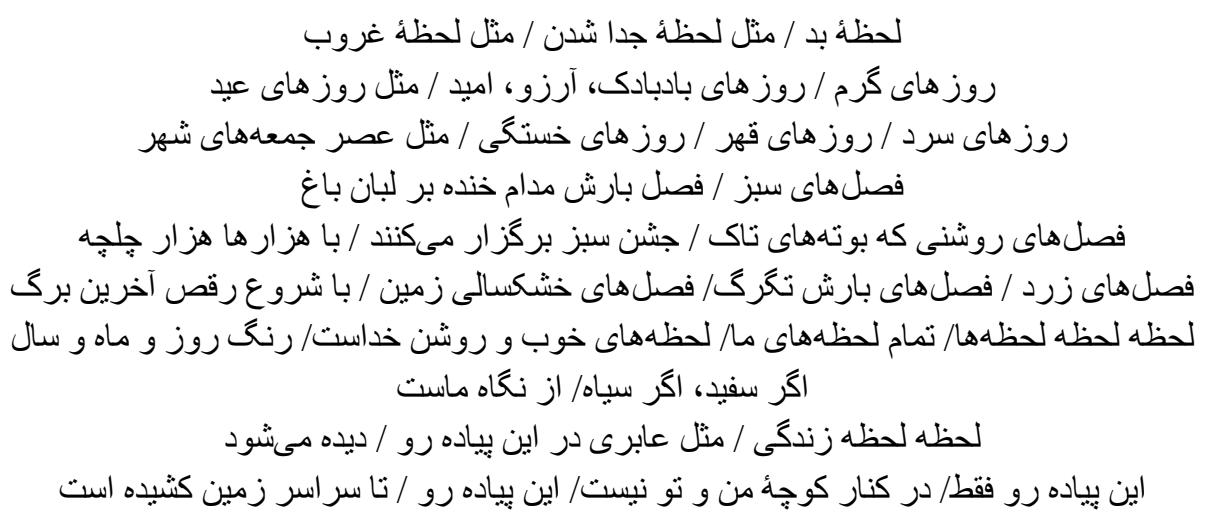

(MALEKI, ALL OVER THE EARTH, 2014: 31).

The child likes works that does not disturb his mind and does not cause semantic confusion; In other words, a work whose meaning and understanding is simple and easy to understand will be pleasing to him. The poet has emphasized the beauty of this work by applying special analogies. He regards the good moments as the beginning of friendship and the more beautiful as the sunrise and the bad moments as separation and sunset. In addition to the analogies that used; the contrast between good and evil, friendship and hostility as well as sunrise and sunset are beautiful. The poet teaches the audience that the good and the bad and the controversy of both are present in life and that life is composed of both kinds of moments. In the phrase "kite days", lexical norms have led to the de-familiarization and consequently the prominence of the word. The poet has likened warm days to wishes, hopes, and feasts and he likens cold days to exhaustion and, consequently, to frustrating Fridays. The contrast between hot and cold days and wishes and hopes and tiredness is not without beauty, but it will be difficult for the audience to understand. Including beliefs that are rooted in religious myths; the appearance of the Savior is in the apocalypse and it belongs to the savior, according to the Friday teachings, and the absence of the savior brings tiredness and anger. The connection between the words "hope and wish" with "Friday evening" adds to the beauty of the work but its interpretation and understanding of the meaning of the word draws the work from the realm of children's and adolescent literature to adult works. The poet interprets the spring as the "green season", the season when the spring rains bring joy to nature. He attributes the rain to "garden laughter". The metaphor used in this phrase is beautiful. This season, accompanied by rain, is a reason to "celebrate the green vine bushes". The poet likened the blossoms and spring flowers to the chandelier, in addition to applying a lively tone. The word "laugh" is ambiguous and in addition to bringing the concept of rain to mind and fitting in with the word rain, it also induces the concept of greenery. One of the concepts that have a mythological root is the word "green". This concept is a symbol of hope and desire and will be associated with words like "bright" and "good 
future." The poet's interpretation of the cold, leafy season is the "yellow season". The season that ground become dry due to hail and cold weather, the contrasts of the "green" and "yellow" colors, the spring precipitation and the hail of the cold season, as well as the contrast of the greenery of the garden and against that cold, deciduous season have added to the beauty of the work. The poet believes that all the moments of life are good, promising and divine; it is us who see them as black or white. The poet likens the moments of life to a crosswalk that is as wide as the whole earth. Understanding such works is difficult or impossible for a specific audience and requires interpretation and explanation.

\subsection{Lack of attention child and adolescent special moods}

Many researchers in the field of children and adolescents believe that expressing political issues and violent and painful events are not pleasant to the audience and it is best to produce a more careful and careful account of such events especially if it lacks artistic elements and is merely mentioned for the purpose of telling the story. Some believe that it is better not to blur the minds of children with such issues and in contrast others believe that it is better to familiarize them with the issues and problems that exist in their community. (GHEZEL AYAGH, 2002: 87). The concept of death is similarly developed during childhood as a multifaceted concept of death in children. Some believe that the process of mourning and the concept of death in children are very different from that of adults (KHOSHBAKHT, 2010: 130). In children's works we sometimes use the following concepts:

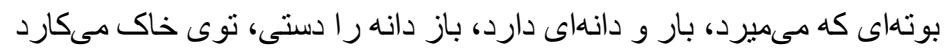

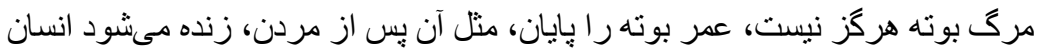

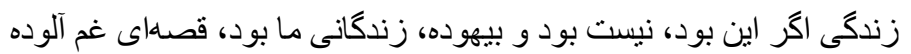

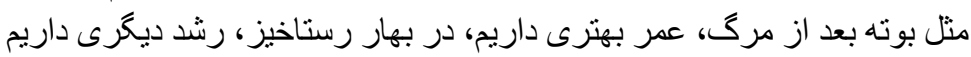

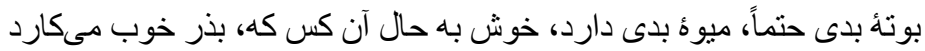

(Spring of Judgment, Mustafa Rahmandoust, the sky is still blue)

The poet expresses his direct and explicit educational messages in the form of poetry, the theme of despair and talk of nothingness and destruction is not only pleasing to the audience, but it will not be understood. The poet of thought and concern about old age has raised concerns for groups that do not yet have a picture of the subject.

\subsection{A Critical Look at Author- based Theory in Child and Adolescent Literature}


Analyzing the psychological and social characteristics of the work and the thought of the author of the work may be influential in the writing of the work. What we get from this definition is that, the author creates a work aimed at conveying social and historical values and concepts rather than addressing the needs of the audience. The researcher, with a critical look at some of the issues that the author has addressed with regard to his own needs and not the audience's:

\subsection{Expressing Social Problems}

Some of the works created for children and adolescents are created solely for specific purposes; That is, the author, instead of paying attention to the characteristics and needs of the audience and writing according to their needs; They create the work with a specific purpose. Like this example of Kianoush depicting the plight of society:

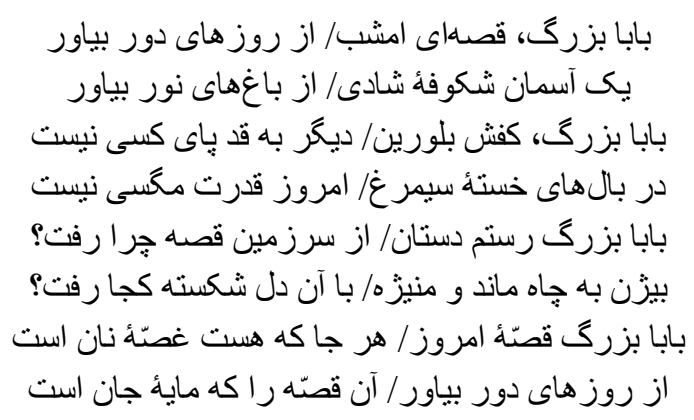

(KIANOUSH, 1991: Children of Heaven, Gardens of Light)

Criticizing the status quo and expressing the problems of the people and the sadness and problems of the language community is not childish rather, it is merely child language and adult expression which is given in this way.

\subsection{Expressing the Author's Thoughts}

The author may express his or her beliefs in language and in the form of a child's work. He may offer a new interpretation of the subject and take a different view of the use of words. For example, following the poet's work to emphasize the theme of his poetry, this is the central focus of his thought; He has come up with a new interpretation of symbols, in particular "yellow and red." 
and the "cage" symbol for "lock in" or, the song is a symbol of freedom, this helps to reinforce the poet's semantic burden.

$$
\begin{aligned}
& \text { زندگى سبز است جون جنكل، زندكى آبى است جون دريا }
\end{aligned}
$$

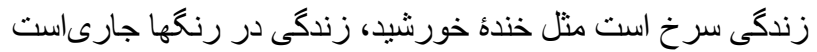

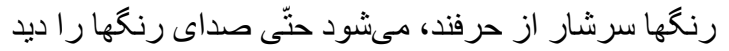

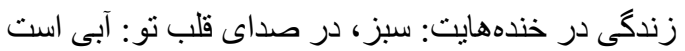

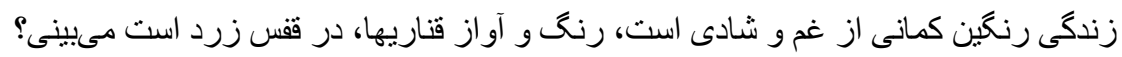

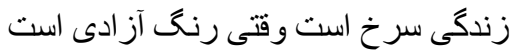

(Sound of Colors, Maliheh Mehrparvar, Blue Qibla)

In the interpretation of "life" after the poetic description it expresses the main theme of the poem. The images are based on an idea of a biological concern whose beauties are conditioned by the color of freedom, red and ideal. The poet emphasizes the value of his thoughts and concerns with greater emphasis. The poet's ingenuity in defining the meaning of symbols can be contemplated. Yellow for captivity, Red for beautiful life, In other words, the poet has reinterpreted the symbols to emphasize the theme of his poetry, which is at the heart of his thought. These sophisticated applications and expression of adult thought in children's works reinforce authorbased theory.

\subsection{Expressing Political Problems}

Another issue that can be addressed in the author-based approach is the issue of political problems in the hidden layers of children's and adolescent literature. The author expresses in an indirect and, albeit orientated, language what he has in and of himself and which he cannot express clearly.

There are different opinions on how to address political issues in children's literature. Some believe that it is better not to blur the minds of children with such issues And in contrast others believe that it is better to familiarize them with the issues and problems that exist in their community (GHEZELAYAGH, 2002: 87).

"There was a huge garden next to the poor, no-water village, full of all kinds of fruit trees and plenty of water. The garden was so big and full of trees that you wouldn't even see it if you were looking at it with a camera.

A few years ago the master of the village relinquished the land and sold it to the villagers; but he had kept the garden for himself. The peasants' lands, however, were not flat and full of trees. 
There was no water. Only the village had a large plain in the middle of the valleys, which were the master garden and some rugged land on top of the hills and valleys that the villagers had bought from their masters and planted wheat and barley. To summarize what we have to say may not be our story. There were two peach trees growing in the garden, one smaller and the other smaller. The leaves and flowers of these two trees were exactly alike, so that everyone would first find out that both trees are the same. The larger tree was linked and each year it brought large, rosy, and beautiful peaches so hard to fit into the fist that one could not bite and eat them. The gardener said that the larger tree had been transplanted by an external engineer who had also brought the transplant from their own country. How much does a peach tree that has spent so much money on it know? At the neck of both trees, they were hung on written prayer boards.

The smaller peach tree would open about a thousand flowers each year, but not one peach. Either he would drop his flowers or his peaches would turn yellow and fall. The gardener would do whatever was best for the smaller tree, but the smaller peach tree would not change. The foliage grows larger year by year, but not even a large peach. The gardener thought of joining the smaller tree, but the tree did not change. Finally the gardener was tired. He wanted to scam and scare the smaller peach tree. He went and saw and he called his wife and in front of the smaller peach tree began to sharpen the saw. After the saw was sharpened, he went back and forth to the smaller peach tree. That, for example, I will now chase you away from the stench and do not spill your peaches until you are..... (BEHRANGI, 1998: One Peach and a Thousand Peaches)"

In this story, as in many other works of the author, there is a conflict between the upper and lower classes of society. "Pulad and Saib Ali" represent and sample the lower classes of society who want to receive their rights in whatever way they can from the masters and the dead and the gardener represents the power imposed on the two children by the upper classes and it prevents them from fulfilling their share of justice. Of course, the manner in which Ali and Pulad are resorting to their rights may not seem very appealing. But planting a peach tree can be a symbol of litigation and the realization of the ideals of the poor. And the tree is a symbol of persistence and endurance in an effort that may not be as fruitful as lawsuits such as Pulad and Saheb Ali but the lords and the rich can never benefit from it. This symbolic look has an unconscious effect on the reader and it brings the work of Behrangi from a mere narrative to a symbolic, idealistic, and believable world. Overall, "One Peach Thousand Peaches" is the story of an effort to bring about justice, with a sweet fruit and a bounty of oppressed people, even if they lose their lives in this way and have not had the chance to taste it in this world. 


\section{CONCLUSION}

Researchers in the field of children's and adolescent literature have long focused on two theories: "Book-based or text-based criticism and child or audience-based criticism" Of course, one can add to these two third theories, author-based criticism. Undoubtedly, by studying and recognizing the impact of the three text-based, author-based and audience-based theories on children's and adolescent literacy, better results can be obtained; therefore, one should not overlook its application to the analysis of children's literature in addition to examining literary criticisms of the great works of adults. Children's literature, like adult literature, has features and delicacies that can be addressed to the audience by its literary criticism and theories and it paved the way for writers in this field to write useful works. The researcher can take a critical look at the works of children and adolescents and examine some of the existing works from the perspective of these theories in the context of the three text-based, audience-based and author-based theories.

In the 'text-based' approach, the critic merely examines and evaluates the text, irrespective of the audience or author, irrespective of the involvement of external factors. He assesses the aesthetics and value of the text and examines the aesthetic elements that make it stand out.

Audience recognition has always been one of the fundamental criteria for criticizing children's literature, some researchers in the field of children's and adolescent literature find audience recognition critical in critique and they believe that critics need to be aware of the child's world before criticizing the work. These scholars focus more on audience recognition than on text or author. Understanding the audience and their subjective characteristics and cognitive understanding of what they read or the book they are writing is important.

An analysis of the psychological and social characteristics of the author and the author's thought of the work or author may be effective in writing. What emerges from this definition is that the author creates a work aimed at conveying social and historical values and concepts.

Thus, the researcher can examine triple theories with a critical view of children's and adolescent works and show the strengths or weaknesses of the work.

\section{REFERENCES}

BAHRANGI, SAMAD. Selected Works of Samad Bahrangi, Selection of Ali Ashraf Darvishian, Tehran: Books and Culture, 1998. 
BURTONS, HANS. Foundations of Literary Theory, Translated by Mohammad Reza Abolghasemi, Second Edition, Tehran: Mahi, 2008.

Dashti, E. Examining the relationship between unwillingness to translate and personality type of Iranian translation students. Journal of Research and Knowledge Spreading, v. 1, n. 1, p. 1-10, 2020.

FOROUZAN, RAZIEH SADAT. Nonsense verse Poems in Children's Literature, Child and Adolescent Month Book, April 93 pages $76-80,2014$.

GHEZEL AAGH, SORAYA. Children's Literature and Promotion and Reading, Tehran: Aram Publications, 2004.

Heckler, V. et al. Investigation with experimental practical activities in training geographically distant teachers. Journal of Research and Knowledge Spreading, v, 1, n. 1, p. 1-15, 2020.

JALALI, MARYAM. Adaptation Indicators in Child and Adolescent Literature: A New Look at Rewriting and Reconstructing the Completion of the Hundred Years Adopted List of Shahnameh in Child and Adolescent Literature, Tehran: Women's Artistic Cultural Association, 2016.

KESHAVARZ, NASSER. Apple John Salam, Tehran: The Center for the Intellectual Development of Children and Youth, First Edition, 1998.

KHOSHBAKHT, FARIBA. Investigating the Concept of Death in Iranian Children's Literature Content Analysis of 9 Storybooks, Journal of Children's Literature Studies, Volume 1, Number 1, 2010.

KIANOUSH, MAHMOOD. Children of Heaven, Tehran: Center for the Intellectual Development of Children and Adolescents, 1991.

MALEKI, BUICK. On the Sidewalk, Tehran: Blossom Books, 2014.

MEHRPARVAR, MALIHEH. the Blue Qibla, Tehran: Surah Mehr, 1997.

NODELMAN ,PERRY. The Hidden Adult :Defining Children's Literature, The Johns Hopkins University Press, 2008.

O'SULLIVAN, EMER. ComparativeChildren'sLiterature, London and New York, 2005.

PETER HUNT. Literature for children contemporary criticism, londonandnewyor, 1992.

POLADI, KAMAL. Children's Literature Foundations, Tehran: Center for the Intellectual Development of Children and Youth, 2005.

RAHMANDOUST, MOSTAFA. The sky is still blue, Tehran: Pen altar, 2001.

SANGARI, MOHAMMAD REZA. the Door to Children's Paradise, Tehran: Sun Rain, 2011.

SEYYED ABADI, ALI ASGHAR. Crossing Traditional Audiences, Tehran: Culture, 2006. 


\title{
ABOUT THE AUTORS
}

\author{
Alireza Saghir \\ Ph.D student of department of Persian language and literature, torbat-e heydariye branch, Islamic \\ Azad University, Torbat- e heydariye, Iran. \\ E-mail: alireza.saghiri@yahoo.com \\ ORCID: https://orcid.org/0000-0003-1972-3180

\section{Mahmoud Firouzimoghaddam} \\ Department of Persian language and literature, torbat-e heydariye branch, Islamic Azad University, \\ Torbat- e heydariye, Iran Corresponding Author. \\ E-mail: firouzimoghaddam@gmail.com \\ ORCID: https://orcid.org/0000-0002-0705-2482

\section{Maryam Jalali} \\ Department of Persian language and literature, torbat-e heydariye branch, Islamic Azad University, \\ Torbat- e heydariye, Iran. \\ E-mail: Jalali 1388@yahoo.com \\ ORCID: https://orcid.org/0000-0001-8926-6881

\section{Mehyar Alavimoghaddam} \\ Department of Persian language and literature, torbat-e heydariye branch, Islamic Azad university, \\ Torbat- e heydariye, Iran \\ E-mail: m.alavi2007@yahoo.com \\ ORCID: https://orcid.org/0000-0003-3570-8845
}

Recebido em: 09-09-2020

Aprovado em: 11-20-2020

Publicado em: 12-02-2020 